\title{
New Bitter-Tasting Hemiterpene Glycosides from the Japanese Fern Hymenophyllum barbatum
}

\author{
Masao Toyota, Yasushi Orso, and Yoshinori Asakawa* \\ Faculty of Pharmaceutical Sciences, Tokushima Bunri University, Yamashiro-cho, Tokushima 770-8514, Japan. \\ Received July 26, 2001; accepted September 4, 2001
}

\begin{abstract}
Hymenosides G-J were newly isolated from the Japanese fern Hymenophyllum barbatum, in addition to hymenosides $A-F$. The structures of hymenosides were elucidated by extensive two-dimensional nuclear magnetic resonance and/or chemical evidence. The structures of those aglycones were divided into three types, 1,4-dihydroxy-2-hydroxymethyl-but-2-ene, 1,4-dihydroxy-2-methyl-but-2-ene, and 3-hydroxy-5-hexanolide. The sugar moieties were also established by chemical and spectroscopic methods, which were acylated by phenylacetic acid derivatives. These glycosides had a bitter or weakly pungent taste.
\end{abstract}

Key words Hymenophyllum barbatum; hemiterpene glycoside; fern; cryptogam

Differing traditional views of the evolutionary relationships between bryophytes and pteridophytes have been presented. If the ferns and bryophytes are indeed close to the main line of evolution of other vascular plants, then indicators of such links may be present in some chemical congruence. In our continuing chemosystematic research on cryptogamous plants, including bryophytes and pteridophytes, we reported that an acyclic bisbibenzyl characteristic of liverworts was present in the fern Hymenophyllum barbatum. ${ }^{1)}$ The compound was considered to be a chemical fossil that could link bryophytes and ferns.

After the extraction of $H$. barbatum with methanol, the crude extract was partitioned between water and ethyl acetate, and then $n$-butanol. The ethyl acetate-soluble fraction was subjected to repeated chromatography on silica gel and Sephadex LH-20 columns, followed by preparative HPLC to yield four hemiterpene glycosides, hymenosides $\mathrm{G}-\mathrm{J}(\mathbf{1}, \mathbf{4}$, 7, 9), together with hymenosides A-F (Fig. 1). ${ }^{1)}$

Hymenoside $\mathrm{G}(\mathbf{1}),[\alpha]_{\mathrm{D}}-26.3^{\circ}$, showed a broad absorption band of a hydroxyl group at $3391 \mathrm{~cm}^{-1}$ and intense carbonyl absorption at $1732 \mathrm{~cm}^{-1}$ in the Fourier transform (FT)IR spectrum. The presence of an aromatic ring was apparent from UV absorption at $284 \mathrm{~nm}$ and signals due to aromatic protons at $\delta 6.87-7.45$ in the ${ }^{1} \mathrm{H}$-nuclear magnetic resonance (NMR) spectrum of $\mathbf{1}$. There were also signals of four oxygenated methylene groups, three isolated arylic methylene groups, five oxygenated methine protons, an olefinic proton, and three sets of protons on a 1,3,4-trisubstituted aromatic ring, as shown in Table 1 . The aromatic protons at $\delta$ $7.33(1 \mathrm{H}, \mathrm{d}, J=2 \mathrm{~Hz})$ and $6.87(1 \mathrm{H}, \mathrm{dd}, J=2,8 \mathrm{~Hz})$ correlated to an isolated methylene carbon at $\delta 39.8(\mathrm{C}-\alpha)$ in the heteronuclear multiple bond correlation (HMBC) spectrum of $\mathbf{1}$. Further correlation between the methylene protons at $\delta 3.66$ and 3.71 (each $1 \mathrm{H}, \mathrm{d}, J=16 \mathrm{~Hz}, \mathrm{H}_{2}-\alpha$ ) and ester carbonyl carbon at $\delta 170.8\left(\mathrm{C}-2^{\prime}-\mathrm{CO}\right)$ was observed in the HMBC spectrum, as shown in Fig. 2. The negative electrospray ionization-mass spectrometry (ESI-MS) showed a quasimolecular ion peak at $m / z 729(\mathrm{M}-\mathrm{H})^{-}$(base peak) and also exhibited a quasi-molecular ion at $m / z 753(\mathrm{M}+\mathrm{Na})^{+}$in the positive ESI-MS. Increasing the fragmentor voltage $(200 \mathrm{~V})$ of negative ESI-MS with collision-induced dissociation (CID) method exhibited a loss of the phenylacetyl groups from the molecular ion peak at $\mathrm{m} / \mathrm{z} 579$ (70\%), 429 (100\%), and 279
$(10 \%)$. This provided further evidence for the presence of phenylacetyl groups in the molecule of $\mathbf{1}$.

Hydrolysis of 1 in $20 \% \mathrm{KOH}$ aqueous solution gave a glycoside 2, of which the ${ }^{1} \mathrm{H}$ - and ${ }^{13} \mathrm{C}$-NMR spectral data were identical to those of $(E)$-4-hydroxy-2-(hydroxymethyl) but-2enyl $\beta$-D-allopyranoside (cardiomanol), which has been isolated from the fern Cardiomanes reniforme (Hymenophyllaceae $)^{2)}$ and also isolated from the present species. To confirm a sugar moiety of $\mathbf{1}$, acidic hydrolysis of $\mathbf{1}$ and $\mathbf{2}$ was performed with $5 \% \mathrm{H}_{2} \mathrm{SO}_{4}$. D- $(+)$-allose was detected as the sugar moiety of 1 by capillary GC-MS of its hexaacetate and HPLC analysis with a chiral detector. Further purification of the resulting mixture of the hydrolysis of 1 gave a 3,4-dihydroxyphenylacetic acid, of which the spectral data were identical to those of the authentic sample. The ${ }^{1} \mathrm{H}-\mathrm{NMR}$ spectrum of 2 showed an anomeric proton at $\delta 5.40(1 \mathrm{H}, \mathrm{d}, J=8 \mathrm{~Hz}, \mathrm{H}-$ $\left.1^{\prime}\right)$, although it was observed at $\delta 5.39$ as broad singlet in the ${ }^{1} \mathrm{H}-\mathrm{NMR}$ spectrum of $\mathbf{1}$. The broad singlet signal was correlated to two methine carbon signals at $\delta 98.0\left(\mathrm{C}-1^{\prime}\right)$ and 70.8 $\left(\mathrm{C}-2^{\prime}\right)$ in the heteronuclear multiple quantum coherence (HMQC) spectrum of $\mathbf{1}$.

It is interesting to note that the chemical shifts of anomeric and $\mathrm{H}-2^{\prime}$ protons of $\mathbf{1}$ had an equivalent in its ${ }^{1} \mathrm{H}-\mathrm{NMR}$ spectrum. Acetylation of $\mathbf{1}$ gave the nonaacetate $\mathbf{3}$, of which the anomeric proton signal was observed at $\delta 5.19(\mathrm{~d}, J=8 \mathrm{~Hz})$ in its ${ }^{1} \mathrm{H}-\mathrm{NMR}$ spectrum. The configuration of the anomeric position of 1 was determined to be $\beta$ on the basis of the coupling constant of the anomeric proton in the ${ }^{1} \mathrm{H}-\mathrm{NMR}$ spectra of $\mathbf{2}$ and $\mathbf{3}$.

The confirmation of the 3,4-dihydroxyphenylacetoxyl-attached position of $\beta$-D-allopyranose was determined as follows. The long-range coupling between ester carbonyl carbons (at $\delta 170.8,171.6,171.7$ ) and $\mathrm{H}^{\prime} 6^{\prime}$ (at $\delta 4.88,4.68$ ), $\mathrm{H}-$ $3^{\prime}$ at $\delta 6.28(\mathrm{t}, J=3 \mathrm{~Hz})$ and $\mathrm{H}-2^{\prime}$ were observed, respectively, in the HMBC spectrum of 1 (Fig. 2). The position at $\mathrm{C}-4^{\prime}$ on the allopyranose remained as a hydroxyl group without acylation by 3,4-dihydroxyphenylacetic acid, since the ${ }^{1} \mathrm{H}-\mathrm{NMR}$ spectrum of the acetate 3 exhibited $\mathrm{H}-4{ }^{\prime}$ at $\delta 5.43$ (dd, $J=8,3 \mathrm{~Hz}$ ) which was shifted downfield by $+1.17 \mathrm{ppm}$ in comparison with that of $\mathbf{1}$. Accordingly, the positions by acylated 3,4-dihydroxyphenylacetic acid were established to be $\mathrm{C}-2^{\prime}, 3^{\prime}$, and $6^{\prime}$ of $\beta$-D-allopyranose in $\mathbf{1}$. Consideration of these chemical and spectral data led to the conclusion that 


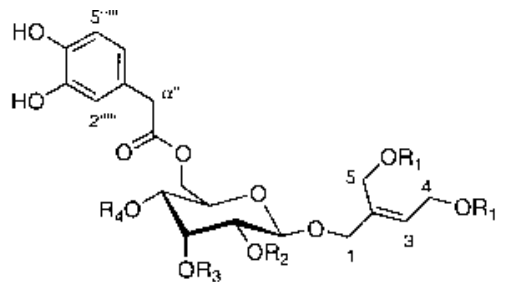

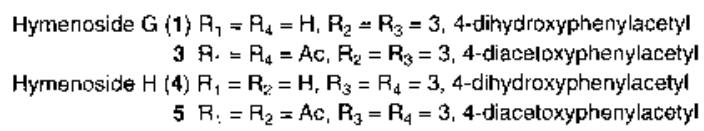<smiles>OC/C=C(\CO)COC1OCC(O)[C@H](O)[C@H](O)[C@H]1O</smiles>

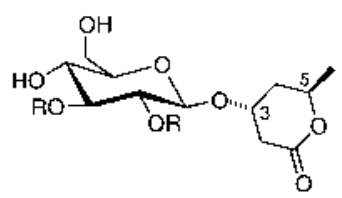

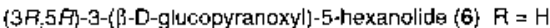
hymenoside I (7) $\mathbf{R}=4$-hydroxypherylacetyl<smiles>C[C@H]1C[C@H](O)CC(=O)O1</smiles>

(3R,5R)-3-hydroxy-5-hexandide (8)

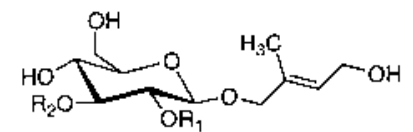

Hymenoside J (9) $\mathrm{R}_{1}=3$, 4-dihydroxyphenylacetyl, $\mathrm{P}_{2}=$ pheny/acet'l|

Hymenoside $A$ (10) $R_{1}=R_{2}=4$-mydroxyphenylacetyl<smiles>O=C(O)Cc1cc(O)ccc1O</smiles>

Homogentisic acid [11)

Fig. 1. Structures of Hymenosides and Related Compounds

the structure of hymenoside $\mathrm{G}$ was 1 .

The structure of hymenoside H (4) was deduced by comparing its spectral data with those of hymenoside G (1). The ESI-MS spectrum of $\mathbf{4}$ showed a quasimolecular ion peak at $\mathrm{m} / \mathrm{z} 729$ and increasing the fragmentor voltage exhibited fragment ion peaks at $m / z 579$ and 429 . The ${ }^{1} \mathrm{H}$ - and ${ }^{13} \mathrm{C}$ NMR spectral data (Table 1) of $\mathbf{4}$ were similar to those of $\mathbf{1}$, except for the difference in the chemical shifts due to signals of $\mathrm{H}-2^{\prime}$ and $4^{\prime}$ in comparison with those of $\mathbf{1}$. Acetylation of 4 gave the nonaacetate 5 . Whereas the ${ }^{1} \mathrm{H}-\mathrm{NMR}$ spectrum of

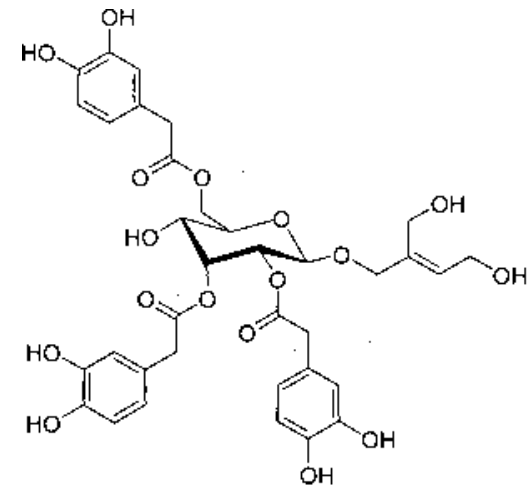

${ }^{1} \mathrm{H}$ to ${ }^{13} \mathrm{C}$

Fig. 2. Structure of Hymenoside G (1) and Its Long-Range Correlations in the HMBC Spectrum

5 showed a signal due to an acetylated methine proton at $\delta$ $4.84\left(\mathrm{dd}, J=8,3 \mathrm{~Hz}, \mathrm{H}-2^{\prime}\right)$ which was shifted downfield in comparison with that of 4 , the chemical shift of a signal at $\delta$ 4.91 (dd, $J=10,3 \mathrm{~Hz}, \mathrm{H}-4^{\prime}$ ) was differed little from that of $\mathbf{4}$. Accordingly, the replacement of the 3,4-dihydroxyphenylacetoxyl group at C-2' to $\mathrm{C}-4^{\prime}$ was confirmed.

While studying the present species, it was observed by chance that part of hymenoside $\mathrm{G}(\mathbf{1})$ is labile to hymenoside H (4). A pure neat sample of hymenoside G (1) was allowed to stand in a refrigerator and after 3 months was found to have changed to 4 . The acetylation of a mixture of 1 and 4 indicated a content of hymenoside $\mathrm{H}$ (4) of $18 \%$, which was estimated by the intensity of an acetyl methyl proton at $\delta$ 1.94 (of 4) in its ${ }^{1} \mathrm{H}-\mathrm{NMR}$ spectrum. On the other hand, pure hymenoside $\mathrm{H} \mathrm{(4)}$ also produced a $15 \%$ content of 1 , which was estimated by the intensity of the signal at $\delta 1.82$ (of $\mathbf{1}$ ). After being allowed to stand further, no more change occurred. This can be explained by a trans-acylation shift of $\mathbf{1}$ to 4 . This prompted us to reexamine the presence of both hymenosides as natural products by liquid chromatographymass spectrometry (LC-MS) of the fresh extract of the fern. Direct LC-MS analysis of a newly prepared $\mathrm{MeOH}$ extract of $H$. barbatum clearly indicated that both hymenosides G (1) and $\mathrm{H} \mathrm{(4)} \mathrm{were} \mathrm{naturally} \mathrm{contained} \mathrm{in} \mathrm{the} \mathrm{fresh} \mathrm{extract.}$

The IR spectrum of $\mathbf{6}$ showed an absorption band for carbonyl and hydroxyl groups at 1715 and $3366 \mathrm{~cm}^{-1}$, and no absorption band for a conjugated system was observed in its UV spectrum. The structure of $\mathbf{6}$ was established by its extensive two-dimensional (2D) NMR spectra to be 3-( $\beta$-glucopyranosyloxy)-5-hexanolide (parasorboside), which has been isolated from the bitter-tasting fruits of mountain ash Sorbus aucuparia L. ${ }^{3,4)}$ Attempts were made to establish the absolute configuration of C-3 and 5, since both diastereomers $(3 S, 5 S)-^{-3)}$ and $\left.(3 R, 5 R)-{ }^{4}\right) 3$-( $\beta$-D-glucopyranosyloxy)-5-hexanolide have been isolated from $S$. aucuparia, the fern $O_{s-}$ munda japonica, ${ }^{5,6)}$ and fruits of Sorbus melanocarpa. ${ }^{7)}$ The absolute configuration was determined by X-ray crystallographic analysis of crystals of its $p$-bromobenzoate crystallized from ethyl acetate. The stereoscopic view of the crystal of $(3 R, 5 R)-3$-( $\beta$-D-glucopyranosyloxy)-5-hexanolide $(\mathbf{6})$ is shown in Fig. 3, and the absolute structure of 6 was confirmed. Assignment of ${ }^{1} \mathrm{H}$ - and ${ }^{13} \mathrm{C}-\mathrm{NMR}$ data for compound $\mathbf{6}$ is described in the Experimental section, as there is no 
Table 1. ${ }^{1} \mathrm{H}$ - and ${ }^{13} \mathrm{C}-\mathrm{NMR}$ Data for Hymenosides G (1) and H (4) in Pyridine- $d_{5}$

\begin{tabular}{|c|c|c|c|c|}
\hline \multirow{2}{*}{ No. } & \multicolumn{2}{|c|}{ Hymenoside G (1) } & \multicolumn{2}{|c|}{ Hymenoside H (4) } \\
\hline & ${ }^{1} \mathrm{H}$ & ${ }^{13} \mathrm{C}$ & ${ }^{1} \mathrm{H}$ & ${ }^{13} \mathrm{C}$ \\
\hline 1 & $\begin{array}{l}4.84,4.65 \\
\text { (each } 1 \mathrm{H}, \text { br d, } 12)\end{array}$ & 71.1 & $\begin{array}{l}4.60,4.87 \\
(\text { each } 1 \mathrm{H}, \mathrm{d}, 12)\end{array}$ & 71.3 \\
\hline 2 & - & 137.1 & - & 137.2 \\
\hline 3 & $6.31(\mathrm{t}, 6)$ & 130.4 & $6.32(\mathrm{t}, 6)$ & 130.9 \\
\hline 4 & $4.62-4.64^{a)}$ & $57.6^{b)}$ & $4.65^{a)}$ & 57.6 \\
\hline 5 & $4.62-4.64^{a)}$ & $57.4^{b)}$ & $4.61(\mathrm{~s})$ & 57.6 \\
\hline $1^{\prime}$ & $5.39(\mathrm{brs})$ & 98.0 & $5.32(\mathrm{~d}, 8)$ & 100.8 \\
\hline $2^{\prime}$ & $5.39(\mathrm{brs})$ & 70.8 & $4.15(\mathrm{dd}, 8,3)$ & 68.8 \\
\hline $3^{\prime}$ & $6.28(\mathrm{t}, 3)$ & 71.7 & $6.34(\mathrm{t}, 3)$ & 71.4 \\
\hline $4^{\prime}$ & $4.26(\mathrm{dd}, 10,3)$ & 65.7 & $5.39(\mathrm{dd}, 10,3)$ & 67.8 \\
\hline $5^{\prime}$ & $4.45(\mathrm{ddd}, 10,6,2)$ & 72.8 & $4.39(\mathrm{ddd}, 10,5,2)$ & 70.0 \\
\hline $6^{\prime}$ & $\begin{array}{l}4.88(\mathrm{dd}, 12,2) \\
4.68(\mathrm{dd}, 12,6)\end{array}$ & 63.9 & $\begin{array}{l}4.46(\mathrm{dd}, 12,2) \\
4.50(\mathrm{dd}, 12,5)\end{array}$ & 62.9 \\
\hline $\mathrm{C}-2^{\prime}-\mathrm{CO}$ & - & 170.8 & & \\
\hline$\alpha$ & $\begin{array}{l}3.66,3.71 \\
(\text { each } 1 \mathrm{H}, \mathrm{d}, 16)\end{array}$ & 39.8 & & \\
\hline $1^{\prime \prime}$ & - & 125.1 & & \\
\hline $2^{\prime \prime}$ & $7.33(\mathrm{~d}, 2)$ & $117.3^{c)}$ & & \\
\hline $3^{\prime \prime}$ & - & $146.4^{d)}$ & & \\
\hline $4^{\prime \prime}$ & - & $145.6^{e)}$ & & \\
\hline $5^{\prime \prime}$ & $7.16(\mathrm{~d}, 8)$ & $115.8^{f)}$ & & \\
\hline $6^{\prime \prime}$ & $6.87(\mathrm{dd}, 8,2)$ & $120.4^{g)}$ & & \\
\hline $\mathrm{C}-3^{\prime}-\mathrm{CO}$ & - & $171.6^{h)}$ & & $171.5^{b)}$ \\
\hline$\alpha^{\prime}$ & $\begin{array}{l}3.72,3.75 \\
(\text { each } 1 \mathrm{H}, \mathrm{d}, 16)^{b)}\end{array}$ & $40.1^{i)}$ & $\begin{array}{l}3.70,3.37 \\
(\text { each } 1 \mathrm{H}, \mathrm{d}, 15)^{b)}\end{array}$ & $40.0^{c)}$ \\
\hline $1^{\prime \prime \prime}$ & - & $125.4^{j)}$ & - & $125.3^{d)}$ \\
\hline $2^{\prime \prime \prime}$ & $7.36(\mathrm{~d}, 2)^{c)}$ & $117.4^{c)}$ & $7.35(\mathrm{~d}, 2)^{c)}$ & $117.4^{e)}$ \\
\hline $3^{\prime \prime \prime}$ & - & $146.6^{d)}$ & - & $145.7^{a)}$ \\
\hline $4^{\prime \prime \prime}$ & - & $145.7^{e)}$ & - & $146.6^{f}$ \\
\hline $5^{\prime \prime \prime}$ & $7.21(\mathrm{~d}, 8)^{d)}$ & $115.9^{f)}$ & $7.21(\mathrm{~d}, 8)^{d)}$ & $115.9^{g)}$ \\
\hline $6^{\prime \prime \prime}$ & $6.93(\mathrm{dd}, 8,2)^{e)}$ & $120.6^{g)}$ & $6.92(\mathrm{dd}, 8,2)^{e)}$ & $120.7^{h)}$ \\
\hline $\mathrm{C}-4^{\prime}-\mathrm{CO}$ & & & - & 170.7 \\
\hline$\alpha^{\prime \prime}$ & & & $3.65(2 \mathrm{H}, \mathrm{s})$ & 39.8 \\
\hline $1^{\prime \prime \prime \prime}$ & & & - & 125.0 \\
\hline $2^{\prime \prime \prime \prime}$ & & & $7.35(\mathrm{~d}, 2)$ & $117.3^{e)}$ \\
\hline $3^{\prime \prime \prime \prime}$ & & & - & $145.7^{a)}$ \\
\hline $4^{\prime \prime \prime \prime}$ & & & - & $146.5^{f)}$ \\
\hline $5^{\prime \prime \prime \prime}$ & & & $7.19(\mathrm{~d}, 8)$ & $115.9^{g)}$ \\
\hline $6^{\prime \prime \prime \prime}$ & & & $6.88(\mathrm{dd}, 8,2)$ & $120.5^{h)}$ \\
\hline $\mathrm{C}-6^{\prime}-\mathrm{CO}$ & - & $171.7^{h)}$ & - & $171.6^{b)}$ \\
\hline$\alpha^{\prime \prime \prime}$ & $\begin{array}{l}3.77,3.86 \\
(\text { each } 1 \mathrm{H}, \mathrm{d}, 15)^{b)}\end{array}$ & $40.5^{i)}$ & $\begin{array}{l}3.79,3.86 \\
(\text { each } 1 \mathrm{H}, \mathrm{d}, 15)^{b)}\end{array}$ & $40.4^{c)}$ \\
\hline $1^{\prime \prime \prime \prime \prime \prime}$ & - & $125.6^{j)}$ & - & $125.6^{d)}$ \\
\hline $2^{\prime \prime \prime \prime \prime}$ & $7.45(\mathrm{~d}, 2)^{c)}$ & $117.5^{c)}$ & $7.45(\mathrm{~d}, 2)^{c)}$ & $117.5^{e)}$ \\
\hline $3^{\prime \prime \prime \prime \prime \prime}$ & - & $146.6^{d)}$ & - & $145.7^{a)}$ \\
\hline $4^{\prime \prime \prime \prime \prime \prime}$ & - & $145.7^{e)}$ & - & $146.7^{f)}$ \\
\hline $5^{\prime \prime \prime \prime \prime}$ & $7.26(\mathrm{~d}, 8)^{d)}$ & $115.9^{f)}$ & $7.24(\mathrm{~d}, 8)^{d)}$ & $116.0^{g)}$ \\
\hline $6^{\prime \prime \prime \prime \prime}$ & $7.02(\mathrm{dd}, 8,2)^{e)}$ & $120.8^{g)}$ & $\left.7.01(\mathrm{dd}, 8,2)^{e}\right)$ & $120.7^{h)}$ \\
\hline
\end{tabular}

a) Overlapping signal. $b-j$ ) Signal assignments may be interchangeable in each column.

exact report of these data in the literature.

The structure of hymenoside I (7) was established by comparing its spectral data with those of the previous compound 6. While the new appearance of two carbonyl carbon signals at $\delta 170.4$ and 171.4 in the ${ }^{13} \mathrm{C}$-NMR spectrum of 7 was observed, the ${ }^{1} \mathrm{H}-{ }^{1} \mathrm{H}$ spin coupling correlation for the $\delta$-lactone aglycone of 7 was identical to that of $\mathbf{6}$. The IR spectrum of 7 showed absorption bands for a carbonyl and an aromatic ring at $1730,1597,1516$, and $839 \mathrm{~cm}^{-1}$. The absorption band at $278 \mathrm{~nm}$ in its UV spectrum provided further evidence for the presence of the aromatic ring. The FAB-MS spectrum of 7 gave a quasimolecular ion peak at $\mathrm{m} / \mathrm{z} 583$ and its high-

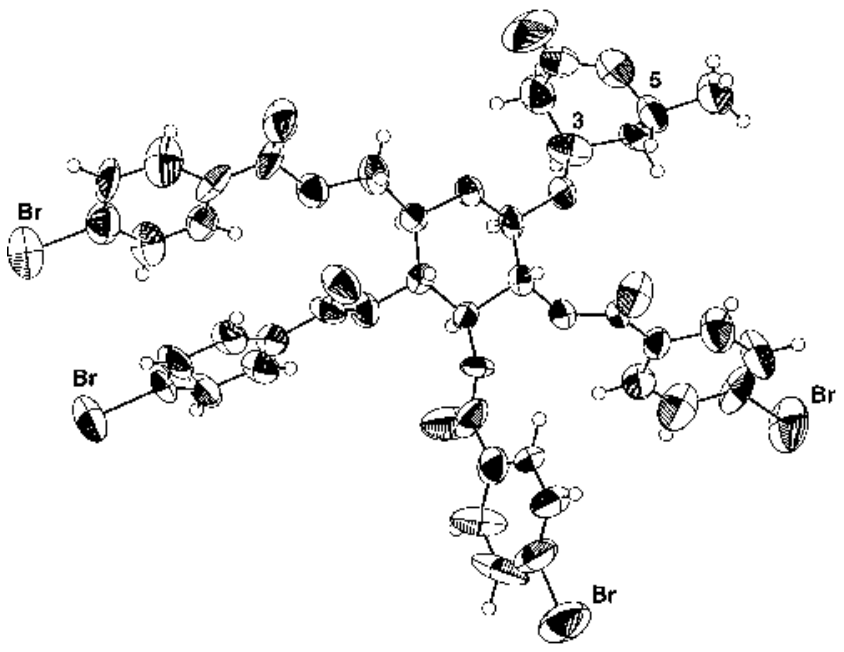

Fig. 3. Computer Generated Drawing of the Final X-Ray Model of $p$-Bromobenzoate of 6

resolution (HR) analysis showed the composition to be $\mathrm{C}_{28} \mathrm{H}_{32} \mathrm{O}_{12} \mathrm{Na}$. The ${ }^{1} \mathrm{H}-\mathrm{NMR}$ spectrum of 7 was similar to that of 6 , except for the chemical shift of two oxygenated methine proton $\left(\mathrm{H}-2^{\prime}, 3^{\prime}\right)$ signals of the glucopyranose moiety and addition of the signals at $\delta 3.57,3.62$, and $3.60(2 \mathrm{H})$ (two methylenes) and aromatic protons at $\delta 7.11,7.14,7.28$, and 7.31 (each $2 \mathrm{H}, \mathrm{d}, J=8.5 \mathrm{~Hz}$ ). The additional proton signal was assignable as the $p$-hydroxyphenylacetic acid moiety of 7. The positive FAB-MS spectrum of 7 showed fragment peaks at $m / z 431$ and 279, which were considered to be fragment ion peaks with the loss of $p$-hydroxyphenylacetic acid from the quasimolecular ion peak of 7. The HMBC spectrum confirmed the structural assignment. The long-range ${ }^{1} \mathrm{H}-{ }^{13} \mathrm{C}$ correlation between the $\mathrm{H}-2^{\prime}$ proton at $\delta 5.42$ and carbonyl carbon at $\delta 170.4$ and long-range coupling with H-3' at $\delta$ 5.84 and the remaining carbonyl carbon at $\delta 171.4$ supported the attachment of the $p$-hydroxyphenylacetoxyl group at C- $2^{\prime}$ and $-3^{\prime}$ on the glucopyranose moiety of 6 .

The absolute configuration of the aglycone was determined by the following chemical means. The enzymatic hydrolysis of compound $\mathbf{6}$ gave an aglycone, (3R,5R)-3-hydroxy-5-hexanolide (8). The analysis of optical purity with LC-MS using a chiral column gave a single peak of $\mathbf{8}$, as shown in Fig. 4A, although synthetic material showed two peaks (racemic composition with $R_{\mathrm{s}}=2.8$ ) on a total ion chromatogram (TIC) (Fig. 4D). After optical resolution of the racemic 8 with lipase PS (Pseudomonas cepacia), the LC-MS analysis showed a single peak at the same $t_{\mathrm{R}}$ as that of the aglycone $\mathbf{8}$ obtained from the hydrolysis of $\mathbf{6}$, as shown in Fig. 4B $(e=98.7 \%)$. The retention time of an aglycone obtained from enzymatic hydrolysis of 7 was identical to that of 8 (Fig. 4C). This was further confirmed by coinjection analysis that showed a single peak on the TIC. The optical rotation, $+38.6^{\circ} \quad\left(\mathrm{CHCl}_{3}, \quad c=3.1\right.$; from $\left.\mathbf{6}\right)$ and $+34.5^{\circ}$ $\left(\mathrm{CHCl}_{3}, c=3.5\right.$; synthetic 8) of the both 3-hydroxy-5-hexanolide was identical, although those sign was opposite to that of $(-)-(3 S, 5 S)-3$-hydroxy-5-hexanolide $\left[-39.7^{\circ}\left(\mathrm{CHCl}_{3}, c=\right.\right.$ $1.57),{ }^{5-7)}-22^{\circ}$ (acetone, $\left.\left.c=0.92\right)^{3)}\right]$. Accordingly, the structure of hymenoside I was elucidated to be 7 .

Hymenoside J (9) was obtained as a colorless viscous oil. The structure of 9 was deduced by extensively comparing the 

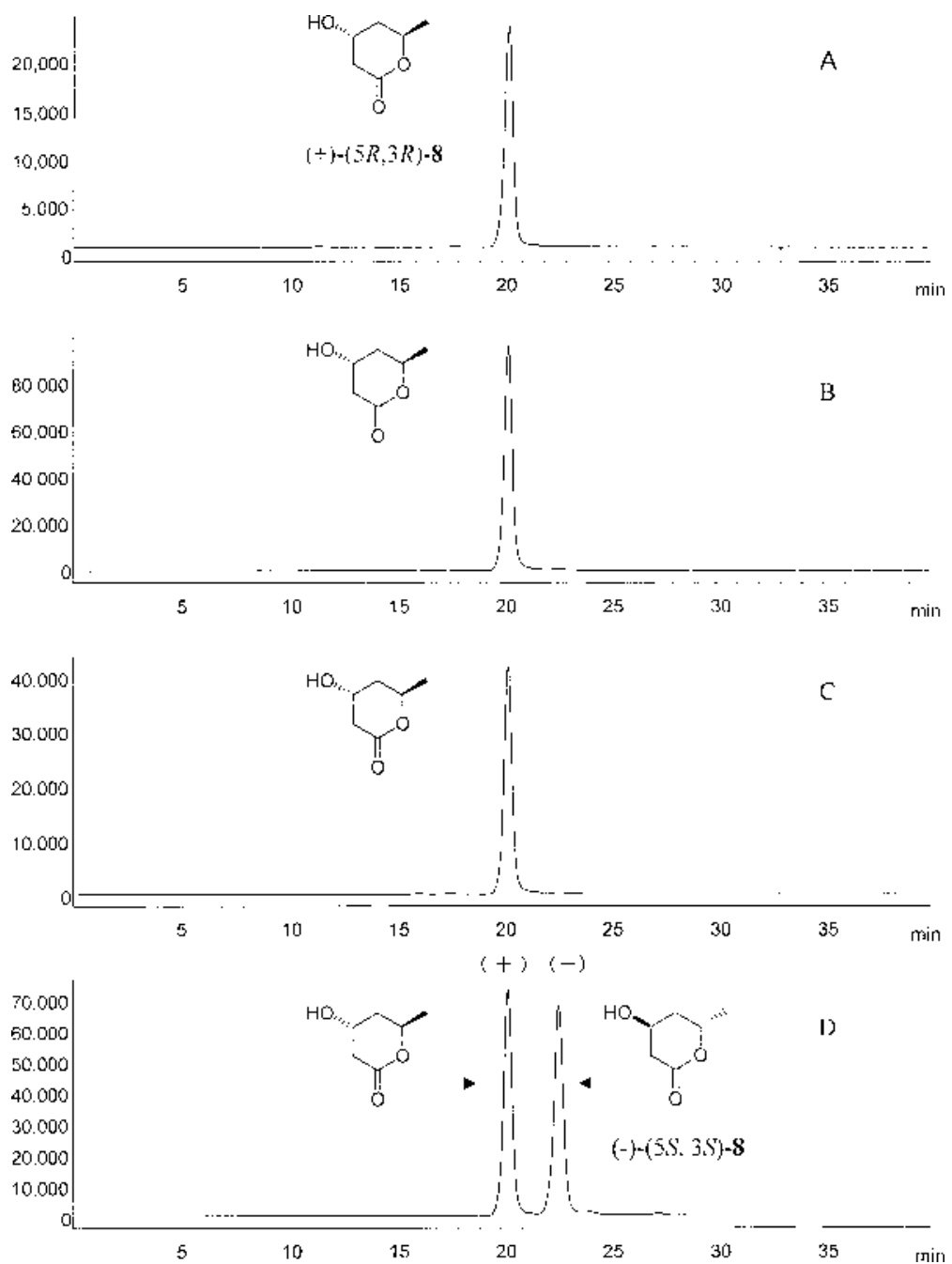

Fig. 4. TIC of LC-MS Analysis

A: (+)-8; obtained from compound $\mathbf{6}$ with enzymatic hydrolysis. B: (+)-8; after optical resolution of synthetic $\mathbf{8}$. C: $(+)-8$; cbtained from enzymatic hydrolysis of hymenoside I (7). D: Racemic compound $\mathbf{8}$ before optical resolution.

spectral data with those of hymenoside A (10), which was isolated from the present species in our previous investigation. ${ }^{1)}$ While the same molecular formula of $\mathrm{C}_{27} \mathrm{H}_{32} \mathrm{O}_{11}$ of $\mathbf{1 0}$ was found in the HR-FAB-MS spectrum of 9, the ${ }^{1} \mathrm{H}-{ }^{1} \mathrm{H}$ spin-coupling pattern of the aromatic ring differs from that of 10. The ${ }^{1} \mathrm{H}-\mathrm{NMR}$ spectrum of 9 was similar to that of 10, except for the above difference. It was clear that 9 has an acylated glucopyranose and 2-methyl-2-buten-4-ol moiety. The ${ }^{1} \mathrm{H}-\mathrm{NMR}$ spectrum of 9 exhibited the presence of 1,3,4- and 1 -substituted aromatic rings by the replacement of two 1,4disubstituted aromatic rings of 10. The HMBC spectrum of 9 showed a correlation between $\mathrm{H}-2^{\prime}$ at $\delta 5.52$ and a carbonyl carbon at $\delta 170.7$, and a further correlation between $\mathrm{H}-3^{\prime}$ at $\delta 5.80$ and $\delta 170.8$ was observed. The HMBC spectrum did not distinguish the acylated positions of $\mathrm{C}-2^{\prime}$ and $3^{\prime}$ on the glucopyranose of 9, since the chemical shifts of the $\alpha$ and $\alpha^{\prime}$ protons of both acyl groups in its ${ }^{1} \mathrm{H}-\mathrm{NMR}$ spectrum in pyridine- $d_{5}$ were same. On the other hand, the HMBC spectrum of 9 in $\mathrm{CD}_{3} \mathrm{OD}$ clearly indicated the presence of a phenylacetoxyl group at $\mathrm{H}-3^{\prime}$ and a 3,4-dihydroxyphenylacetoxyl group at $\mathrm{H}-2^{\prime}$ of 9 . The above evidence led to the conclusion that hymenoside $\mathrm{J}(\mathbf{9})$ only differed from hymenoside A (10) in the replacement of two $p$-hydroxyphenylacetoxyl groups by phenylacetoxyl (at C-3') and 3,4-dihydroxyphenylacetoxyl (at C-2') groups.

Hymenosides $\mathrm{G}$ - J had a bitter taste, but have not yet been evaluated quantitatively. The tasted compound, 2,5-dihydroxyphenylacetic acid (homogentisic acid) (11) has an acrid taste and its distribution in the plant kingdom is known. ${ }^{8,9)}$ It is considered necessary for the bitter taste for phenylacetic acid derivatives to be attached to glucose as esters, at least for the isolated taste compounds in the present investigation. The screening of the biological activities of those compounds is in progress.

\section{Experimental}

General Experimental Procedures TLC was carried out on silica gel precoated glass plates with $\mathrm{CHCl}_{3}-\mathrm{MeOH}(4: 1,7: 3)$ or $\mathrm{CHCl}_{3}-\mathrm{MeOH}-$ $\mathrm{H}_{2} \mathrm{O}(15: 6: 1,65: 35: 5)$. Detection was performed with Godin reagent. For normal-phase column chromatography $(\mathrm{CC})$, silica gel $60(40-63 \mu \mathrm{m})$ was used. The mixture of $\mathrm{CH}_{2} \mathrm{Cl}_{2}-\mathrm{MeOH}(1: 1)$ was used for $\mathrm{CC}$ on Sephadex LH-20 as a solvent. The melting point was determined using a Yanagimoto micro melting point apparatus and is uncorrected. Optical rotations were recorded on a JASCO DP-1000 automatic digital polarimeter. NMR spectra were recorded at 150 and $75 \mathrm{MHz}$ for ${ }^{13} \mathrm{C}$ and 600 and $300 \mathrm{MHz}$ for ${ }^{1} \mathrm{H}$ on a Varian UNITY 600 and Varian MERCURY 300, respectively. The chemical shifts are given in $\delta(\mathrm{ppm})$ with tetramethylsilane as an internal standard. UV spectra were recorded in spectroscopic-grade EtOH on a Hitachi U- 
3000. IR spectra were measured on a JASCO FT/IR-41. GC-MS spectra were recorded on a Hewlett-Packard HP-6890 gas chromatograph with a 5972A mass selective detector. The temperature programming for GC-MS analysis was performed from $70^{\circ} \mathrm{C}$ isothermal for $3 \mathrm{~min}$, then at $70-250^{\circ} \mathrm{C}$ at $5{ }^{\circ} \mathrm{C} / \mathrm{min}$, and finally isothermal at $250^{\circ} \mathrm{C}$ for $15 \mathrm{~min}$. The injection temperature was $250^{\circ} \mathrm{C}$. A fused silica column coated with DB-17 $(30 \mathrm{~m} \times 0.25 \mathrm{~mm}$ i.d., film thickness $0.25 \mu \mathrm{m})$ was used. LC-MS spectra were measured on a Hewlett-Packard HP 1100 MSD.

Extraction and Isolation of Compounds H. barbatum was collected in August 1997 in Kaifu-gun, Tokushima. The air-dried and mechanically ground powder $(2.42 \mathrm{~kg})$ was extracted with methanol for 1 month at room temperature to give a crude extract $(459.2 \mathrm{~g})$. Fresh H. barbatum $(1 \mathrm{~g})$ was collected in the same location and was gently washed with water, impurities removed and the plant material ground in a mortar with $\mathrm{MeOH}$ and then filtered through a short pad column $(20 \mathrm{~mm} \times 5 \mathrm{~mm}$ i.d. $)$ on celite. Part of the eluent was analyzed by LC-MS.

Part $(70.0 \mathrm{~g})$ of the ethyl acetate-soluble fraction $(119.6 \mathrm{~g})$ was chromatographed on Sephadex LH-20, giving four fractions (I-IV). The first fraction $(3.7 \mathrm{~g})$ was rechromatographed on Sephadex LH-20 to give a mixture of hymenosides I and $\mathrm{J}$, which was further purified by silica gel $\mathrm{CC}$ using $\mathrm{CHCl}_{3}-\mathrm{MeOH}-\mathrm{H}_{2} \mathrm{O}$, followed by HPLC [column; COSMOSIL 5C18AR-II, i.d. $6 \times 250 \mathrm{~mm}$, mobile phase; $\left.\mathrm{MeOH}-\mathrm{H}_{2} \mathrm{O}(3: 2 \mathrm{v} / \mathrm{v}), 2 \mathrm{ml} / \mathrm{min}\right]$ to yield two hemiterpene glycosides, hymenosides I and $\mathrm{J}(\mathbf{7}, 12.8 \mathrm{mg} ; \mathbf{9}$, $5.6 \mathrm{mg})$. The third fraction $(24.0 \mathrm{~g})$ was repeatedly chromatographed on silica gel using $\mathrm{CHCl}_{3}-\mathrm{MeOH}-\mathrm{H}_{2} \mathrm{O}$, then repeatedly on a Lobar column on RP-18 to give a mixture of hymenosides $\mathrm{G}$ and $\mathrm{H}$ which was purified by HPLC using $\mathrm{MeOH}-\mathrm{H}_{2} \mathrm{O}$ to give hymenoside $\mathrm{G}(\mathbf{1}, 19.9 \mathrm{mg})$ and $\mathrm{H}(\mathbf{4}$, $27.9 \mathrm{mg})$.

Part $(70.0 \mathrm{~g})$ of the $n$-BuOH-soluble fraction $(158.0 \mathrm{~g})$ was chromatographed on HP-20, giving seven fractions (I-VII). The second fraction $(5.3 \mathrm{~g})$ was repeatedly chromatographed on Sephadex LH-20 and on silica gel to give a mixture. The mixture was further purified by Lobar RP-8 to yield a mixture of 6 . The isolation of (3R,5R)-3-( $\beta$-D-glucopyranosyloxy)-5hexanolide $(6,375.5 \mathrm{mg})$ was performed by Lobar CN CC.

Hymenoside G (1): An oil, positive HR-FAB-MS m/z: 753.1995 (Calcd for $\mathrm{C}_{35} \mathrm{H}_{38} \mathrm{O}_{17} \mathrm{Na}$ : 753.2006), $[\alpha]_{\mathrm{D}}^{22}-26.3^{\circ}(c=1.0, \mathrm{MeOH}), \mathrm{IR}(\mathrm{KBr}) \mathrm{cm}^{-1}$ : $3391,1732,1606,1352,1286$. UV $\lambda_{\max }(\mathrm{EtOH}) \mathrm{nm}(\log \varepsilon): 284(4.08), 203$ (5.01). ${ }^{1} \mathrm{H}-$ and ${ }^{13} \mathrm{C}$-NMR: Table 1.

Hymenoside H (4): An oil, positive HR-FAB-MS m/z: 753.1970 (Calcd for $\left.\mathrm{C}_{35} \mathrm{H}_{38} \mathrm{O}_{17} \mathrm{Na}: 753.2006\right),[\alpha]_{\mathrm{D}}^{22}+10.9^{\circ}(c=1.4, \mathrm{MeOH}), \mathrm{IR}(\mathrm{KBr}) \mathrm{cm}^{-1}$ : $3376,1736,1607,1356,1287$. UV $\lambda_{\max }(\mathrm{EtOH}) \mathrm{nm}(\log \varepsilon): 283.5$ (3.97), 203.5 (4.89). ${ }^{1} \mathrm{H}$ - and ${ }^{13} \mathrm{C}$-NMR: Table 1.

Hymenoside I (7): An oil, positive HR-FAB-MS m/z: 583.1765 (Calcd for $\left.\mathrm{C}_{28} \mathrm{H}_{32} \mathrm{O}_{12} \mathrm{Na}: 583.1791\right),[\alpha]_{\mathrm{D}}^{22}-20.9^{\circ}(c=0.64, \mathrm{MeOH}), \mathrm{IR}(\mathrm{KBr}) \mathrm{cm}^{-1}$ : $3399,1730,1259,1597,1516,839$. UV $\lambda_{\max }(\mathrm{EtOH}) \mathrm{nm}(\log \varepsilon): 277.8$ (3.62), 226.8 (4.18), 201.2 (4.53). ${ }^{1} \mathrm{H}$ - and ${ }^{13} \mathrm{C}-\mathrm{NMR}$ : Table 2.

Hymenoside J (9): An oil, positive HR-FAB-MS m/z: 555.1808 (Calcd for $\left.\mathrm{C}_{27} \mathrm{H}_{32} \mathrm{O}_{11} \mathrm{Na}: 555.1842\right),[\alpha]_{\mathrm{D}}^{22}-38.7^{\circ}(c=2.82, \mathrm{MeOH}), \mathrm{IR}(\mathrm{KBr}) \mathrm{cm}^{-1}$ : $3320,1736,1588,1262,1076$. UV $\lambda_{\text {max }}($ EtOH) nm $(\log \varepsilon): 204$ (4.60), 283 (3.60). ${ }^{1} \mathrm{H}$ - and ${ }^{13} \mathrm{C}$-NMR: Table 3 .

$(3 R, 5 R)-3$-( $\beta$-D-Glucopyranosyloxy)-5-hexanolide (6): An oil; FAB-MS $m / z: 315(\mathrm{M}+\mathrm{Na}) ;[\alpha]_{\mathrm{D}}^{22}-21.8^{\circ}(c=1.62, \mathrm{MeOH}) ;[\alpha]_{\mathrm{D}}^{19}-29.0^{\circ}(c=1.62$, $\left.\mathrm{H}_{2} \mathrm{O}\right)$; IR (KBr) cm ${ }^{-1}: 3366,1715,1263,1074$. ' $\mathrm{H}-\mathrm{NMR}$ (300 MHz; Pyridine- $\left.d_{5}\right) \delta: 1.14(3 \mathrm{H}, \mathrm{d}, J=6 \mathrm{~Hz}, \mathrm{H}-6), 1.54(1 \mathrm{H}, \mathrm{ddd}, J=14,11,3 \mathrm{~Hz}, \mathrm{H}-4)$, $2.22(1 \mathrm{H}$, br ddd, $J=14,5,3 \mathrm{~Hz}, \mathrm{H}-4), 2.81(1 \mathrm{H}, \mathrm{dd}, J=17,5 \mathrm{~Hz}, \mathrm{H}-2), 2.99$ (1H, br ddd, $J=17,3,2 \mathrm{~Hz}, \mathrm{H}-2$ ) , 3.92-4.00 (overlapping signals, $2 \mathrm{H}, \mathrm{H}-2^{\prime}$, $5^{\prime}$ ), $4.16-4.26$ (overlapping signals, $\left.2 \mathrm{H}, \mathrm{H}-3^{\prime}, 4^{\prime}\right), 4.34(1 \mathrm{H}, \mathrm{dd}, J=12$, $\left.6 \mathrm{~Hz}, \mathrm{H}-6^{\prime}\right), 4.54\left(1 \mathrm{H}, \mathrm{dd}, J=12,2 \mathrm{~Hz}, \mathrm{H}-6^{\prime}\right), 4.52(1 \mathrm{H}, \mathrm{br} \mathrm{s}, \mathrm{H}-3), 4.91(1 \mathrm{H}$, d, $\left.J=8 \mathrm{~Hz}, \mathrm{H}-1^{\prime}\right), 5.02(\mathrm{~m}, \mathrm{H}-5) ;{ }^{13} \mathrm{C}-\mathrm{NMR}\left(75 \mathrm{MHz}\right.$; pyridine- $\left.d_{5}\right) \delta: 21.3$ (C-6), 34.2 (C-4), 37.4 (C-2), 62.7 (C-6'), 69.5 (C-3), 71.5 (C-4'), 72.4 (C5), $74.8\left(\mathrm{C}-2^{\prime}\right), 78.4,78.5\left(\mathrm{C}-3^{\prime}, 5^{\prime}\right), 102.4\left(\mathrm{C}-1^{\prime}\right), 170.1(\mathrm{C}-1)$.

Acid Hydrolysis of Hymenoside G (1) A solution of 1 (32 mg) in $5 \% \mathrm{H}_{2} \mathrm{SO}_{4}(2 \mathrm{ml})$ was heated under reflux for $2 \mathrm{~h}$, then diluted with water and extracted with $n$-BuOH. After evaporation, the residue was chromatographed on silica gel to yield 3,4-dihydroxyphenylacetic acid $(3.8 \mathrm{mg})$, for which the spectral data were identical to those of the authentic sample. To confirm the identification, it was methylated with trimethylsilyldiazomethane $(1 \mathrm{ml})$ in $\mathrm{MeOH}(1 \mathrm{ml})$ to give methyl-2,3-dimethoxyphenylacetate $(4.7 \mathrm{mg})$, for which the spectral data were identical to those of authentic material.

Basic Hydrolysis of Hymenoside G (1) A solution of $\mathbf{1}(10 \mathrm{mg})$ in $20 \%$ $\mathrm{KOH}(2 \mathrm{ml})$ was heated under reflux for $2 \mathrm{~h}$. The reaction mixture was extracted with $n$-BuOH and evaporated to yield $2(1.4 \mathrm{mg})$. The ${ }^{1} \mathrm{H}$ - and ${ }^{13} \mathrm{C}-$ NMR spectral data were identical to those of (E)-4-hydroxy-2-(hydrox-
Table 2. NMR Spectral Data of Hymenoside I (7) in Pyridine- $d_{5}$

\begin{tabular}{llr}
\hline \hline \multicolumn{1}{c}{ No. } & \multicolumn{1}{c}{${ }^{1} \mathrm{H}$} & ${ }^{13} \mathrm{C}$ \\
\hline 1 & - & 169.1 \\
2 & $2.77(\mathrm{dd}, 5,17.3), 2.94(\mathrm{ddd}, 1.5,3.5,17.3)$ & 36.6 \\
3 & $4.29(\mathrm{~m})$ & 70.2 \\
4 & $1.51(\mathrm{ddd}, 3,11,14.5), 1.86(\mathrm{brd}, 14.5)$ & 34.2 \\
5 & $4.61(\mathrm{~m})$ & 71.7 \\
6 & $1.17(\mathrm{~d}, 6.3)$ & 20.8 \\
$1^{\prime}$ & $4.97(\mathrm{~d}, 8)$ & 99.4 \\
$2^{\prime}$ & $5.42(\mathrm{dd}, 8,10)$ & 72.2 \\
$3^{\prime}$ & $5.84(\mathrm{dd}, 9.3,10)$ & 76.0 \\
$4^{\prime}$ & $4.31(\mathrm{dd}, 9.3,10)$ & 68.2 \\
$5^{\prime}$ & $3.91(\mathrm{ddd}, 2,5,10)$ & 78.0 \\
$6^{\prime}$ & $4.26(\mathrm{dd}, 5,12), 4.40(\mathrm{dd}, 2,12)$ & 61.1 \\
$\mathrm{C}-2^{\prime}-\mathrm{CO}$ & - & 170.4 \\
$\alpha$ & $3.57(\mathrm{~d}, 15.4), 3.62(\mathrm{~d}, 15.4)$ & 39.9 \\
$1^{\prime \prime}$ & - & 124.2 \\
$2^{\prime \prime}\left(6^{\prime \prime}\right)$ & $7.28(\mathrm{~d}, 8.5)$ & 130.4 \\
$3^{\prime \prime}\left(5^{\prime \prime}\right)$ & $7.11(\mathrm{~d}, 8.5)$ & 115.7 \\
$4^{\prime \prime}$ & - & 157.4 \\
$\mathrm{C}-3^{\prime}-\mathrm{CO}$ & - & 171.4 \\
$\alpha^{\prime}$ & $3.60(\mathrm{~s})$ & 40.0 \\
$1^{\prime \prime \prime}$ & - & 124.5 \\
$2^{\prime \prime \prime}\left(6^{\prime \prime \prime}\right)$ & $7.31(\mathrm{~d}, 8.5)$ & 130.5 \\
$3^{\prime \prime \prime}\left(5^{\prime \prime \prime}\right)$ & $7.14(\mathrm{~d}, 8.5)$ & 115.8 \\
$4^{\prime \prime \prime}$ & - & 157.5 \\
\hline
\end{tabular}

Table 3. NMR Data of Hymenoside J (9) in Pyridine- $d_{5}$

\begin{tabular}{|c|c|c|}
\hline No. & ${ }^{1} \mathrm{H}$ & ${ }^{13} \mathrm{C}$ \\
\hline 1 & $4.06,4.24$ (each d, 12) & 73.9 \\
\hline 2 & - & 132.1 \\
\hline 3 & 5.97 (brt, 6.5) & 128.6 \\
\hline 4 & $4.41($ br d, 6.5) & 57.9 \\
\hline 5 & $1.60(\mathrm{~s})$ & 13.2 \\
\hline $1^{\prime}$ & $4.84(\mathrm{~d}, 8.2)$ & 99.6 \\
\hline \multirow[t]{2}{*}{$2^{\prime}$} & $5.52(\mathrm{dd}, 9.6,8)$ & 72.2 \\
\hline & $4.81(\mathrm{dd}, 9.8,10)^{a)}$ & $73.2^{a)}$ \\
\hline \multirow[t]{2}{*}{$3^{\prime}$} & $5.80(\mathrm{t}, 9.6)$ & 76.3 \\
\hline & $5.10(\mathrm{t}, 10)^{a)}$ & $76.9^{a}$ \\
\hline $4^{\prime}$ & $4.30(\mathrm{t}, 9.6)$ & 68.2 \\
\hline $5^{\prime}$ & $3.82(\mathrm{ddd}, 9.6,5,2)$ & 77.7 \\
\hline $6^{\prime}$ & $4.27(\mathrm{dd}, 12,5), 4.39(\mathrm{dd}, 12,2)$ & 61.0 \\
\hline \multirow[t]{2}{*}{$\mathrm{C}-2^{\prime}-\mathrm{CO}$} & - & 170.7 \\
\hline & & $172.4^{a)}$ \\
\hline \multirow[t]{2}{*}{$\alpha$} & $3.59,3.65$ (each d, 15) & 40.1 \\
\hline & $3.17,3.22\left(\right.$ each d, 15) $\left.{ }^{a}\right)$ & $41.3^{a)}$ \\
\hline $1^{\prime \prime}$ & - & 125.1 \\
\hline \multirow[t]{2}{*}{$2^{\prime \prime}$} & $7.33(\mathrm{~d}, 2)$ & 117.3 \\
\hline & $6.65(\mathrm{~d}, 2)^{a)}$ & $117.5^{a)}$ \\
\hline $3^{\prime \prime}$ & - & 146.6 \\
\hline $4^{\prime \prime}$ & - & 145.8 \\
\hline $5^{\prime \prime}$ & $7.19(\mathrm{~d}, 8)$ & 115.9 \\
\hline \multirow[t]{2}{*}{$6^{\prime \prime}$} & $6.88(\mathrm{dd}, 2,8)$ & 120.5 \\
\hline & $6.48(\mathrm{dd}, 2,8)^{a)}$ & $121.9^{a)}$ \\
\hline \multirow[t]{2}{*}{$\mathrm{C}-3^{\prime}-\mathrm{CO}$} & - & 170.8 \\
\hline & & $172.9^{a)}$ \\
\hline \multirow[t]{2}{*}{$\alpha^{\prime}$} & $3.59,3.65($ each d, 15$)$ & 40.6 \\
\hline & $3.49,3.54(\text { each d, } 15)^{a)}$ & $41.8^{a)}$ \\
\hline $1^{\prime \prime \prime}$ & - & 134.2 \\
\hline $2^{\prime \prime \prime}\left(6^{\prime \prime \prime}\right)$ & $7.30(2 \mathrm{H}$, br d, 8.5) & 129.2 \\
\hline $3^{\prime \prime \prime}\left(5^{\prime \prime \prime}\right)$ & $7.22(2 \mathrm{H}$, br t, 8.5) & 128.2 \\
\hline $4^{\prime \prime \prime}$ & $7.15($ br t, 8.5$)$ & 126.6 \\
\hline
\end{tabular}

a) In $\mathrm{CD}_{3} \mathrm{OD}$.

ymethyl)-but-2-enyl $\beta$-D-allopyranoside (cardiomanol). ${ }^{2)}$

Acid Hydrolysis of 2 A solution of $2(1.4 \mathrm{mg})$ in $5 \% \mathrm{H}_{2} \mathrm{SO}_{4}(2 \mathrm{ml})$ was heated under reflux for $2 \mathrm{~h}$, and then the reaction mixture was passed 
through a DOWEX-1 column. The eluate was concentrated in vacuo and the residue was dissolved in $\mathrm{H}_{2} \mathrm{O}(2 \mathrm{ml})$. Part of the solution was analyzed by HPLC with a chiral detector, JASCO OR-990 [column: ZORBAX SB-C18, i.d. $3.0 \times 250 \mathrm{~mm}$; mobile phase, $\mathrm{CH}_{3} \mathrm{OH}-\mathrm{H}_{2} \mathrm{O}(1: 1 \mathrm{v} / \mathrm{v})$; column oven temperature, $25^{\circ} \mathrm{C}$; flow rate, $0.5 \mathrm{ml} / \mathrm{min}$; compared with (+)- $\beta$-allose]. (+)-Allose was detected. $\mathrm{NaBH}_{4}(10 \mathrm{mg})$ was added to the remaining solution and stirred for $3 \mathrm{~h}$ at room temperature. After neutralization by adding acetic acid, the mixture was evaporated to dryness by repeated codistillation with $\mathrm{MeOH}$. The resulting residue was allowed to stand in $\mathrm{Ac}_{2} \mathrm{O}-\mathrm{C}_{5} \mathrm{H}_{5} \mathrm{~N}(1: 1$ $\mathrm{v} / \mathrm{v}, 2 \mathrm{ml}$ ) overnight at room temperature. A sample was subjected to GC-MS analysis to give the alditol acetate of allose. The identification was performed by coinjection with authentic alditol acetate of allose.

Acetylation of Hymenosides G (1) and $\mathbf{H}(4)$ Compounds 1 and 4 (1, $9.9 \mathrm{mg} ; 4,9.8 \mathrm{mg}$ ) was acetylated with $\mathrm{Ac}_{2} \mathrm{O}$ and $\mathrm{C}_{5} \mathrm{H}_{5} \mathrm{~N}$ (each $0.2 \mathrm{ml}$ ) overnight. The acetate $3(7.2 \mathrm{mg}$ from $\mathbf{1})$ and acetate $5(5.6 \mathrm{mg}$ from 4$)$ were obtained, respectively, after purification with preparative HPLC using a normal-phase column [column, NUCLEOSIL 50-5, i.d. $7.5 \times 250 \mathrm{~mm}$; mobile phase, EtOAc- $n$-hexane $(1: 1 \mathrm{v} / \mathrm{v}), 2 \mathrm{ml} / \mathrm{min}]$.

Compound 3: An oil; positive HR-FAB-MS $m / z$ : $1131.2920(\mathrm{M}+\mathrm{Na})^{+}$ (Calcd for $\mathrm{C}_{53} \mathrm{H}_{56} \mathrm{O}_{26} \mathrm{Na}$ : 1131.2959); $[\alpha]_{\mathrm{D}}^{22}-5.6^{\circ}\left(c=1.36, \mathrm{CHCl}_{3}\right)$; IR (neat) $\mathrm{cm}^{-1}: 1747,1371,1213 ;{ }^{1} \mathrm{H}-\mathrm{NMR}\left(600 \mathrm{MHz}, \mathrm{CDCl}_{3}\right) \delta: 1.82(3 \mathrm{H}, \mathrm{s})$, $2.06(6 \mathrm{H}, \mathrm{s}), 2.25(3 \mathrm{H}, \mathrm{s}), 2.27(12 \mathrm{H}, \mathrm{s}), 2.28(3 \mathrm{H}, \mathrm{s}), 4.02(1 \mathrm{H}, \mathrm{brd}$, $J=13 \mathrm{~Hz}, \mathrm{H}-1), 4.27(1 \mathrm{H}, \mathrm{dd}, J=13,1 \mathrm{~Hz}, \mathrm{H}-1), 5.79(1 \mathrm{H}, \mathrm{t}, J=7 \mathrm{~Hz}, \mathrm{H}-3)$, 4.71, 4.75 (each $1 \mathrm{H}, \mathrm{dd}, J=13,7 \mathrm{~Hz}, \mathrm{H}-4), 4.59,4.62$ (each $1 \mathrm{H}, \mathrm{d}, J=12 \mathrm{~Hz}$, $\mathrm{H}-5), 4.61\left(1 \mathrm{H}, \mathrm{d}, J=8 \mathrm{~Hz}, \mathrm{H}-1^{\prime}\right), 4.86\left(1 \mathrm{H}, \mathrm{dd}, J=8,3 \mathrm{~Hz}, \mathrm{H}-2^{\prime}\right), 5.62(1 \mathrm{H}$, t, $\left.J=3 \mathrm{~Hz}, \mathrm{H}-3^{\prime}\right), 4.87\left(1 \mathrm{H}, \mathrm{dd}, J=9,3 \mathrm{~Hz}, \mathrm{H}-4^{\prime}\right),[5.43(\mathrm{dd}, J=10,3 \mathrm{~Hz}, \mathrm{H}-$ $4^{\prime}$ in pyridine- $\left.\left.d_{5}\right)\right], 3.78\left(1 \mathrm{H}\right.$, ddd, $\left.J=9,4,2 \mathrm{~Hz}, \mathrm{H}-5^{\prime}\right), 4.09(1 \mathrm{H}, \mathrm{dd}, J=12$, $\left.4 \mathrm{~Hz}, \mathrm{H}-6^{\prime}\right), 4.21\left(1 \mathrm{H}, \mathrm{dd}, J=12,2 \mathrm{~Hz}, \mathrm{H}-6^{\prime}\right), 7.08-7.17(9 \mathrm{H}, \mathrm{m}$, aromatic ring), 3.56, 3.58 (each $1 \mathrm{H}, \mathrm{d}, J=16 \mathrm{~Hz}), 3.58(2 \mathrm{H}, \mathrm{s}), 3.61,3.64$ (each $1 \mathrm{H}, \mathrm{d}$, $J=16 \mathrm{~Hz}) \cdot{ }^{13} \mathrm{C}$-NMR $(150 \mathrm{MHz}) \mathrm{CDCl}_{3}: \delta 20.3,20.57,20.61,20.8,20.9$ (overlapping signals, q, $-\mathrm{OCOCH}$ ) $, 40.0,40.2,40.5\left(\mathrm{t}, \mathrm{C}-\alpha, \alpha^{\prime}, \alpha^{\prime \prime}\right), 59.5(\mathrm{t}$, C-5), 60.2 (t, C-4), 62.5 (t, C-6'), $66.0\left(\mathrm{~d}, \mathrm{C}-4^{\prime}\right), 68.7$ (d, C-3'), 69.4 (d, C2'), 69.9 (d, C-5'), 70.5 (d, C-1), 97.7 (d, C-1'), 123.36, 123.39, 123.41 (d, C-5", 5"', $\left.5^{\prime \prime \prime \prime}\right), 124.35,124.42,124.50$ (d, C-2"', $\left.2^{\prime \prime \prime}, 2^{\prime \prime \prime \prime}\right), 127.0$ (d, C-3), 127.3, 127.4, 127.5 (d, C-6", 6"', 6'"') $) 132.1,132.3,132.5$ (s, C-1", $\left.1^{\prime \prime \prime}, 1^{\prime \prime \prime \prime}\right)$, 134.8 (s, C-2), 141.16, 141.21, 141.27, 141.90, 141.94, 142.1 (s, C-3", 3"', $\left.3^{\prime \prime \prime \prime}, 4^{\prime \prime}, 4^{\prime \prime \prime}, 4^{\prime \prime \prime \prime}\right), 168.02,168.08,168.13,168.19,168.21,168.9,169.0,169.5$, 170.5, 170.6, 170.7 (overlapping signals, $\mathrm{s}, \mathrm{C}=\mathrm{O}$ ).

Compound 5: An oil; positive HR-FAB-MS $m / z: 1131.2990(\mathrm{M}+\mathrm{Na})^{+}$ (Calcd for $\left.\mathrm{C}_{53} \mathrm{H}_{56} \mathrm{O}_{26} \mathrm{Na}: 1131.2958\right)$; $[\alpha]_{\mathrm{D}}^{22}-8.4^{\circ}\left(c=1.43, \mathrm{CHCl}_{3}\right)$; IR (neat) $\mathrm{cm}^{-1}: 1745,1372,1211 ;{ }^{1} \mathrm{H}-\mathrm{NMR}\left(600 \mathrm{MHz}, \mathrm{CDCl}_{3}\right) \delta: 1.94(3 \mathrm{H}, \mathrm{s})$, $2.05(3 \mathrm{H}, \mathrm{s}), 2.06(3 \mathrm{H}, \mathrm{s}), 2.25(3 \mathrm{H}, \mathrm{s}), 2.26(6 \mathrm{H}, \mathrm{s}), 2.27(6 \mathrm{H}, \mathrm{s}), 2.28(3 \mathrm{H}$, s), $4.03(1 \mathrm{H}, \mathrm{dd}, J=13,1 \mathrm{~Hz}, \mathrm{H}-1), 4.28(1 \mathrm{H}, \mathrm{dd}, J=13,1 \mathrm{~Hz}, \mathrm{H}-1), 5.79$ $(1 \mathrm{H}, \mathrm{t}, J=7 \mathrm{~Hz}, \mathrm{H}-3), 4.71(1 \mathrm{H}, \mathrm{dd}, J=13.5,7 \mathrm{~Hz}, \mathrm{H}-4), 4.73(1 \mathrm{H}, \mathrm{dd}$, $J=13.5,7 \mathrm{~Hz}, \mathrm{H}-4), 4.59(1 \mathrm{H}, \mathrm{d}, J=12.6 \mathrm{~Hz}, \mathrm{H}-5), 4.63(1 \mathrm{H}, \mathrm{d}, J=12.6 \mathrm{~Hz}$, H-5), $4.57\left(1 \mathrm{H}, \mathrm{d}, J=8 \mathrm{~Hz}, \mathrm{H}-1^{\prime}\right), 4.84\left(1 \mathrm{H}, \mathrm{dd}, J=8,3 \mathrm{~Hz}, \mathrm{H}-2^{\prime}\right), 5.63(1 \mathrm{H}$, t, $\left.J=3 \mathrm{~Hz}, \mathrm{H}-3^{\prime}\right), 4.91\left(1 \mathrm{H}, \mathrm{dd}, J=10,3 \mathrm{~Hz}, \mathrm{H}-4^{\prime}\right), 3.82$ (1H, ddd, $J=10,4$, $\left.2 \mathrm{~Hz}, \mathrm{H}-5^{\prime}\right), 4.07\left(1 \mathrm{H}, \mathrm{dd}, J=12.3,4 \mathrm{~Hz}, \mathrm{H}-6^{\prime}\right), 4.18(1 \mathrm{H}, \mathrm{dd}, J=12.3,2 \mathrm{~Hz}$, H-6') $6.99(1 \mathrm{H}, \mathrm{dd}, J=8,2 \mathrm{~Hz}), 7.01(1 \mathrm{H}, \mathrm{d}, J=2 \mathrm{~Hz}), 7.09(1 \mathrm{H}, \mathrm{d}$, $J=8 \mathrm{~Hz}), 7.13-7.16(6 \mathrm{H}, \mathrm{m}) .{ }^{13} \mathrm{C}-\mathrm{NMR}(150 \mathrm{MHz}) \mathrm{CDCl}_{3}: \delta 20.4,20.56$, 20.61, 20.8, 20.9 (overlapping signals, $\mathrm{q},-\mathrm{OCOCH}_{3}$ ), 39.9 (t, C- $\left.\alpha^{\prime}\right), 40.2$, $40.5\left(\mathrm{t}, \mathrm{C}-\alpha, \alpha^{\prime \prime}\right), 59.5(\mathrm{t}, \mathrm{C}-5), 60.2(\mathrm{t}, \mathrm{C}-4), 62.4\left(\mathrm{t}, \mathrm{C}-6^{\prime}\right), 66.4\left(\mathrm{~d}, \mathrm{C}-4^{\prime}\right)$, $68.8\left(\mathrm{~d}, \mathrm{C}-2^{\prime}\right), 69.8\left(\mathrm{~d}, \mathrm{C}-5^{\prime}\right), 70.5(\mathrm{t}, \mathrm{C}-1), 97.9\left(\mathrm{~d}, \mathrm{C}-1^{\prime}\right), 123.41,123.42(\mathrm{~d}$, $\left.\mathrm{C}-5^{\prime \prime}, 5^{\prime \prime \prime}, 5^{\prime \prime \prime}\right), 124.38,124.43$ (overlapping signals, d, C-2", 2"', $\left.2^{\prime \prime \prime \prime}\right), 126.9$ (d, C-3), 127.2, 127.4, 127.6 (d, C-6", 6"', 6"') ), 131.9, 132.3, 132.5 (s, C-1", $\left.1^{\prime \prime \prime}, 1^{\prime \prime \prime \prime}\right), 134.7$ (s, C-2), 141.21, 141.22, 141.29, 141.92, 141.94, 142.1 (s, C$\left.3^{\prime \prime}, 3^{\prime \prime \prime}, 3^{\prime \prime \prime \prime}, 4^{\prime \prime}, 4^{\prime \prime \prime}, 4^{\prime \prime \prime \prime}\right), 168.02,168.07,168.12,168.19,168.20,168.9$, $169.0,169.6,170.5,170.6,170.7$ (overlapping signals, $\mathrm{s}, \mathrm{C}=\mathrm{O}$ ).

Benzoylation of Compound 6 A mixture of $6(29.3 \mathrm{mg})$, dimethyl amino pyridine $(20 \mathrm{mg})$ and $p$-bromobenzoyl chloride $(100 \mathrm{mg})$ was allowed to stand at room temperature overnight. The reaction mixture was filtered through a short pad column on silica gel to give a tetra-benzoyl derivative of $6(73.4 \mathrm{mg})$, followed by purification with Sephadex LH-20 CC $\left[\mathrm{CH}_{2} \mathrm{Cl}_{2}-\mathrm{CH}_{3} \mathrm{OH}(1: 1 \mathrm{v} / \mathrm{v})\right]$. $p$-Bromobenzoate of $\mathbf{6}$; a colorless crystal (from EtOAc); mp 215-217 ${ }^{\circ} \mathrm{C}$; positive FAB-MS $m / z: 1023(\mathrm{M}+1)^{+}, 1025$ $(\mathrm{M}+3)^{+}, 1027(\mathrm{M}+5)^{+} ;[\alpha]_{\mathrm{D}}^{20}+13.5^{\circ}\left(c=3.6, \mathrm{CHCl}_{3}\right)$; IR (neat) $\mathrm{cm}^{-1}$ : 1730, 1589, 1068.

X-Ray Crystallographic Analysis of $\boldsymbol{p}$-Bromobenzoate of 6 Refraction data were measured with a Mac Science MXC18 diffractometer using $\operatorname{MoK} \alpha(\lambda=0.71073 \AA)$ radiation. Monoclinic $P 2_{1} . a=17.830999 \AA, b=$ $6.652000 \AA, c=18.337999 \AA, \beta=102.988998^{\circ}, V=2119.399902 \AA^{3}, Z=2$, $D_{\mathrm{x}}=1.530 \mathrm{mg} \cdot \mathrm{m}^{-3}, \mathrm{ETA}=0.956$. Final residuals $R$ and $R_{\mathrm{w}}$ with 0.1992 and 0.2392 .

Enzymatic Hydrolysis of 6 and Hymenoside I (7) with $\boldsymbol{\beta}$-Glucosidase A solution of $\mathbf{6}$ or hymenoside I (7) $(\mathbf{6}, 32 \mathrm{mg} ; \mathbf{7}, 5 \mathrm{mg})$ in $\mathrm{H}_{2} \mathrm{O}(1 \mathrm{ml})$ was added to a solution of $\beta$-glucosidase (Nacalai tesque; $\beta$-glucosidase from sweet almond; $20 \mathrm{mg}$ ) in $\mathrm{H}_{2} \mathrm{O}(1 \mathrm{ml})$ and stirred at $37^{\circ} \mathrm{C}$ overnight. The mixture was evaporated to dryness. The residue was chromatographed on silica gel $\left[\mathrm{CHCl}_{3}-\mathrm{CH}_{3} \mathrm{OH}(9: 1 \mathrm{v} / \mathrm{v})\right]$ to give $(3 R, 5 R)$-3-hydroxy-5-hexanolide (8) (6.2 mg from 6, $0.4 \mathrm{mg}$ from 7$),[\alpha]_{\mathrm{D}}+38.6^{\circ}\left(c=3.1, \mathrm{CHCl}_{3}\right)$ from 6 . The spectral data and specific optical rotation of 8 were identical to those of synthetic material.

Synthesis and Optical Resolution of 3-Hydroxy-5-hexanolide with Lipase PS A suspension of Ra-Ni (ca. $2.5 \mathrm{~g})$ in EtOH (15 ml) was stirred for $1 \mathrm{~h}$ under hydrogen atmosphere and 4-hydroxy-6-methyl-2-pyrone $(5 \mathrm{~g})$ was added. The mixture was stirred overnight and filtered. The filtrate was evaporated to dryness, and the residual mixture was directly chromatographed on silica gel [EtOAc- $n$-hexane $(1: 1 \mathrm{v} / \mathrm{v})$ ] to give 3-hydroxy-5-hexanolide $(\mathbf{8}$, $350 \mathrm{mg})$.

A mixture of racemic compound $8(350 \mathrm{mg})$ and lipase PS $(670 \mathrm{mg})$ in tert-butyl methyl ether $(13 \mathrm{ml})$ was acetylated with vinyl acetic acid $(6.7 \mathrm{ml})$ at room temperature overnight. The resulting mixture was evaporated to dryness, and then the residue was subjected to chromatographed on silica gel [EtOAc- $n$-hexane $(1: 1 \mathrm{v} / \mathrm{v})]$ to give a $(3 R, 5 R)$-3-hydroxy-5-hexanolide (8) $(140 \mathrm{mg})$. An oil; positive EI-MS $m / z: 130(\mathrm{M})^{+} ;[\alpha]_{\mathrm{D}}^{20}+34.5^{\circ}(c=3.5$, $\mathrm{CHCl}_{3}$ ); IR (neat) $\mathrm{cm}^{-1}: 3426,1697,1246,1056$; CD: $\Delta \varepsilon_{232.3 \mathrm{~nm}}-0.30$ $(c=0.0478 \mathrm{M}, \mathrm{EtOH}) ;{ }^{1} \mathrm{H}-\mathrm{NMR}\left(300 \mathrm{MHz} ; \mathrm{CDCl}_{3}\right): \delta 1.40(3 \mathrm{H}, \mathrm{d}, J=6 \mathrm{~Hz})$, $1.73(1 \mathrm{H}, \mathrm{ddd}, J=14,11,3 \mathrm{~Hz}), 1.99(1 \mathrm{H}$, dddd, $J=14,5,3,2 \mathrm{~Hz}), 2.61(1 \mathrm{H}$, ddd, $J=18,4,2 \mathrm{~Hz}), 2.73(1 \mathrm{H}, \mathrm{dd}, J=18,5 \mathrm{~Hz}), 4.39(1 \mathrm{H}$, br q, $J=4 \mathrm{~Hz})$, $4.85(1 \mathrm{H}, \mathrm{m}) ;{ }^{13} \mathrm{C}-\mathrm{NMR}\left(75 \mathrm{MHz} ; \mathrm{CDCl}_{3}\right): \delta 22.0,38.3,39.0,63.4,73.0$, 171.3.

Acknowledgements We are grateful to Professor Shigeru Daigobou (Joetsu University of Education, Joetsu, Niigata, Japan) for the identification of fern species. We thank to Mr. Shigeru Takaoka (Tokushima Bunri University) for his measurement of $X$ ray crystallographic analysis. This work was supported by a Grand-in-Aid for Scientific Research (A) (No. 11309012) from the Ministry of Education, Culture, Sports, Science and Technology.

\section{References}

1) Oiso Y., Toyota M., Asakawa Y., Chem. Pharm. Bull., 49, 126-128 (2001).

2) Redgwell R. J., Beever R. E., Bieleski R. L., Laracy E. P., Carbohydr. Res., 198, 39- 48 (1990).

3) Tschesche R., Hoppe H-J., Snatzke G., Wulff G., Fehlhaber, H.-W., Chem. Ber., 104, 1420-1428 (1971).

4) Pyyzsalo H, Kuusi T., Suomen Kemistilehti B, 44, 393-396 (1971).

5) Numata A., Takahashi C., Fujiki R., Kitano E., Kitajima A., Takemura T., Chem. Pharm. Bull., 38, 2862-2865 (1990).

6) Numata A., Hokimoto K., Takemura T., Katsuno T., Yamamoto K., Chem. Pharm. Bull., 32, 2815-2820 (1984).

7) Weinges K., Schick H., Schilling G., Irngartinger H., Oeser T., Eur. J. Org. Chem., 1, 189-192 (1998).

8) Maruyama E., Uehara K., Kajita T., Hasegawa C., Kaseigaku Kenkyu, 29, 1 -5 (1982).

9) Morishita T., Mukogawa Joshi Daigaku Kiyo, Shokumotsu-hen, 27, $39-43$ (1980). 